\title{
Failure of therapy or resistance to antiplatelet drugs?
}

\author{
Hana Ševčíková, Jan Vojáček, Radek Pudil, Josef Štásek, Josef Bis, Róbert Ševčík, Jaroslav Malý*, \\ Petr Dulíček*, Miroslav Pecka*, Ilona Fátorová* \\ Department of Internal Medicine I, *Department of Internal Medicine II - Clinical Hematology, University Hospital \\ Hradec Králové and Charles University in Prague, Medical Faculty in Hradec Králové, Hradec Králové, Czech Republic
}

Ševčíková H, Vojáček J, Pudil R, et al. Failure of therapy or resistance to antiplatelet drugs? Cor Vasa 2009;51(1):41-44.

Even though the efficacy of acetylsalicylic acid (ASA) and clopidogrel has been documented in patients with acute and chronic coronary artery disease (CAD), many patients develop thrombotic cardiovascular complications despite dual antiplatelet therapy due to nonresponsiveness or partial responsiveness. The phenomenon of resistance to antiplatelet therapy remains incompletely defined, influenced as it is by a variety of genetic, cellular, and clinical factors. In conclusion, although clinical guidelines still do not support routine screening for antiplatelet drug resistance (because a standard laboratory assay is still lacking), there is mounting evidence for the need to correlate the laboratory and clinical parameters of platelet activity assessment in different clinical scenarios.

Key words: Acetylsalicylic acid - Clopidogrel - "Nonresponsiveness" - Screening - Aggregometry

\section{Ševčíková H, Vojáček J, Pudil R, et al. Selhání léčby nebo rezistence vůči antiagregačním lékům? Cor Vasa 2009;51(1):41-44.}

Někteří pacienti s ischemickou chorobou srdeční navzdory duální antiagregaci (a prokázanému prospěchu léčby kyselinou acetylsalicylovou a clopidogrelem) trpí rekurentními trombotickými kardiovaskulárními príhodami. Př́činou může být, že pacient nereaguje na antiagregační léky a jejich účinek. Tzv. fenomén rezistence na protidestičkové léky zůstává nadále nedostatečně definován; je ovlivněn řadou genetických, buněčných a klinických faktorů. Závěrem Ize říci, že ačkoli vzhledem k absenci optimální testovací metody není monitorování účinnosti protidestičkové léčby v rutinní klinické praxi podporováno, dostupné údaje poukazují na nutnost monitorování a optimalizace léčby v jednotlivých klinických situacích.

Klíčová slova: Kyselina acetylsalicylová - Clopidogrel - „Rezistence“- Monitorování - Agregometrie

Address: Department of Internal Medicine I, University Hospital Hradec Králové and Charles University in Prague, Medical Faculty in Hradec Králové, Sokolská 581, 50005 Hradec Králové, Czech Republic, e-mail: ha.sevcikova@seznam.cz

\begin{tabular}{|llll|}
\hline Abbreviations & & \\
ASA & acetylsalicylic acid & GP & glycoprotein \\
CAD & coronary artery disease & vWf & von Willebrand factor \\
STEMI & myocardial infarction with ST-segment elevations & CYP 450 & cytochrome P450 (superfamily of hemoproteins) \\
PCI & percutaneous coronary intervention & CYP 2C19 & subfamilies of cytochromes P450 \\
LTA & light transmission aggregometry & P2Y12, P2Y1 & G-protein coupled receptors for ADP \\
CPG & cationic propyl gallate & Mo & monocytes \\
PFA-100 & Platelet Function Analyser-100 & Ma & macrophages \\
PGF & prostaglandin F & ADP & adenosine diphosphate \\
COX 1,2 & cyclooxygenase 1,2 & NSAID & non-steroidal anti-inflammatory drug \\
mRNA & messenger ribonucleic acid & CABG & coronary artery bypass graft \\
TxA2 & thromboxane A2 & PAR & protease activated receptor \\
R & receptor for TxA2 & AA & arachidonic acid \\
\hline
\end{tabular}

Project No. 9174-3 supported by the Internal Grant Agency (Ministry of Health, Czech Republic). 
The benefit of acetylsalicylic acid (ASA) and clopidogrel treatment is well established in patients with coronary artery disease (CAD). A schematic representation of platelet activation mechanisms and sites of action of antiplatelet drugs is shown in Figure 1 below. The role of ASA in primary prevention was shown in the Physician's Health Study. ${ }^{(1)}$ ASA administration reduces mortality in acute myocardial infarction (ISIS-2). ${ }^{(1,2)}$ The CAPRIE, CURE, CREDO, CLARITY-TIMI-38 studies reviewed the efficacy of antiplatelet therapy. Dual antiplatelet therapy in acute coronary syndromes has been shown to reduce cardiovascular mortality (by 20\%) (CURE). ${ }^{(2,3)}$ CREDO demonstrated the efficacy of clopidogrel pretreatment $(26.9 \%$ relative risk reduction) in patients undergoing percutaneous coronary intervention (PCI). ${ }^{(2)}$ Some patients suffer recurrent cardiovascular events despite daily antiplatelet therapy. These patients have been considered resistant or partially responsive to antiplatelet drugs. The definition, diagnosis, prevalence, causes, and clinical consequences of antiplatelet resistance are still uncertain. ${ }^{(4)}$ There is no clear and accepted definition for ASA or clopidogrel resistance. The term resistance to a drug should be used when a drug is unable to hit its pharmacological target. ${ }^{(4)}$ Laboratory resistance to antiplatelet drugs describes the inability of ASA or clopidogrel to block platelet aggregation in vitro. ${ }^{(1-3,5,6)}$ Clinical resistance has been used to show occurrence of cardiovascular events despite antiplatelet therapy. ${ }^{(1-3,5)}$ It is incorrect to consider all patients on ASA treatment experiencing atherothrombotic events resistant to ASA. This phenomenon has been named clinical resistance but it should be more appropriately termed treatment failure. ${ }^{(4)}$ An association between laboratory resistance and clinical outcomes has been shown in some studies. Laboratory ASA resistance was associated with an increased cardiovascular risk. ${ }^{(2,3)}$ High urinary 11-dehydrothromboxane B2 levels despite ASA treatment were associated with higher risk of cardiovascular events (HOPE study). Clopidogrel resistance was studied in patients with acute myocardial infarction after percutaneous coronary intervention. Up to $25 \%$ of

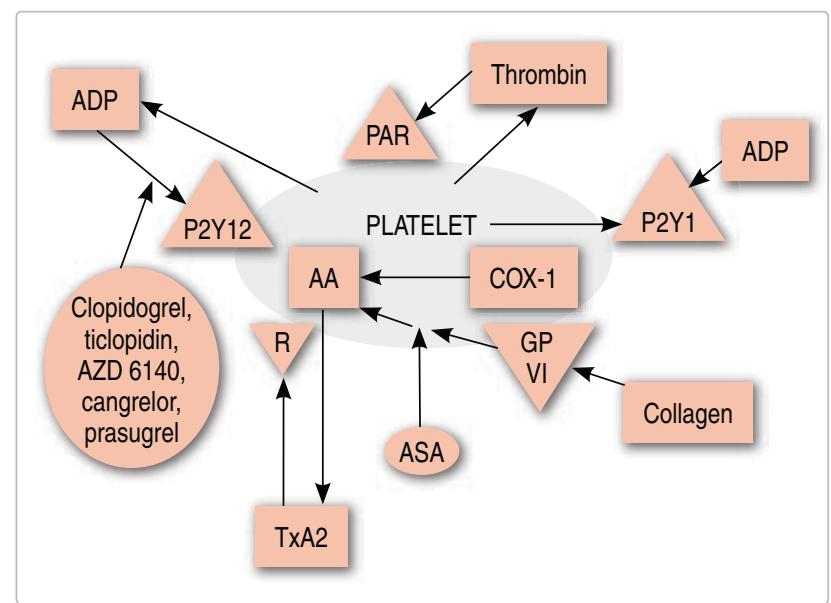

Figure 1 Simple schematic representation of platelet activation mechanisms + site of action of main antiplatelet drugs (adjusted in agreement with Storey $\mathrm{RF}^{(21)}$ and Michos $\mathrm{ED}^{(3)}$ )
STEMI patients undergoing primary PCI were resistant to clopidogrel and showed an increased incidence of recurrent cardiovascular events compared with clopidogrel responders. ${ }^{(3)}$ The prevalence of ASA resistance varies from 5 to $60 \%$ (depending on study population, the used assays, ASA dosage, duration of treatment, patients' comorbidities etc.). ${ }^{(3)}$ Prevalence of clopidogrel nonresponsiveness has been reported in $5-44 \% .{ }^{(7)}$ The exact prevalence of aspirin resistance in patients with stable coronary artery disease remains unclear (due to differences in study populations, lack of formal definition of aspirin responsiveness, and use of non-standardized diagnostic methods). ${ }^{(8)}$ The etiology of both ASA and clopidogrel nonresponsiveness is multifactorial, there are many extrinsic (clinical) and intrinsic (laboratory, genetics) factors modifying platelets functions (Tables 1, 2). Inflammation in acute coronary syndrome could be the basis of failure of antithrombotic therapy. ${ }^{(9,11)}$ The term aspirin resistance should be limited to situations whereby failure of the drug to hit its pharmacological target has been documented with a specific laboratory test. The term clinical resistance to aspirin should not be used to identify situations in which ASA is unable to prevent atherothrombotic events. ${ }^{(4)}$ Although global tests measuring platelet activation in vitro may identify patients with high residual platelet reactivity, they do not necessarily identify those resistant to aspirin. ${ }^{(4)}$ Clinical guidelines still do not

Table 1 Intrinsic factors of antiplatelet resistance ${ }^{(1-3,7,10,14,16)}$

\begin{tabular}{|c|c|}
\hline CELLULAR & GENETICS \\
\hline $\begin{array}{l}\text { ASA, P2Y independent platelet } \\
\text { activation (red blood cells, } \\
\text { thrombin, collagen, } \\
\text { epinephrine, ADP, cytokine- } \\
\text {-induced platelet activation) }\end{array}$ & $\begin{array}{l}\text { - Gene polymorphisms } \\
\text { in COX-1, COX-2, TxA2 } \\
\text { synthase }\end{array}$ \\
\hline $\begin{array}{l}\text { - } \uparrow \text { Sensitivity to collagen } \\
\text { and ADP }\end{array}$ & $\begin{array}{l}\text { - Gene polymorphisms } \\
\text { of GPIa/lla, Ib/V/IX, Ilb/llla } \\
\text { receptor }\end{array}$ \\
\hline $\begin{array}{l}\text { - Overexpression of COX-2 } \\
\text { and COX-2 mRNA in higher } \\
\text { platelet turnover }\end{array}$ & $\begin{array}{l}\text { - Gene polymorphisms } \\
\text { of collagen or vWf } \\
\text { receptor }\end{array}$ \\
\hline $\begin{array}{l}\text { Regeneration of COX-1 } \\
\text { (Mo, Ma, endothelial cells), } \\
\text { insufficient suppression } \\
\text { of COX-1 }\end{array}$ & $\begin{array}{l}\text { - Gene polymorphisms } \\
\text { of XIII (val 34leu) } \\
\text { - P2Y1 single nucleotide } \\
\text { polymorphism }\end{array}$ \\
\hline - Resolvins & $\begin{array}{l}\text { - Polymorphism } \\
\text { of the P2Y12 gene }\end{array}$ \\
\hline 8-iso-PGF 2 & $\begin{array}{l}\text { - Polymorphisms } \\
\text { of the CYP-450 gene } \\
\text { (CYP 3A5, CYP 2C19) }\end{array}$ \\
\hline \multicolumn{2}{|l|}{ - Variations in CYP-450 activity } \\
\hline \multicolumn{2}{|l|}{ - Higher platelet turnover } \\
\hline \multicolumn{2}{|l|}{$\begin{array}{l}\text { Alternative pathways } \\
\text { of platelet activation }\end{array}$} \\
\hline \multicolumn{2}{|l|}{$\begin{array}{l}\text { Variation in number } \\
\text { of receptors for ADP }\end{array}$} \\
\hline - Increased ADP levels & \\
\hline
\end{tabular}


Table 2 Extrinsic factors of antiplatelet resistance ${ }^{(1-3,7,10,14,16)}$

- Non-compliance

- Malabsorption

- Drug-drug interactions (NSAID, ....)

- Smoking

- Stress, postural reaction, obesity

- Age, gender

- Higher platelet turnover (post-CABG, stress reaction, catecholamine surge, ...)

- Hyperlipidemia, hyperglycemia, heart failure

- Nonthrombotic etiology of coronary syndromes

- Hypercoagulation (in acute coronary syndromes)

- Dose dependence

support routine screening for aspirin and clopidogrel resistance due to the lack of a standard diagnostic assay. ${ }^{(3,10)}$ This is because the definition of the most appropriate platelet function assay has not been established and because of the lack of clinical trials showing an impact on clinical outcomes. ${ }^{(10)}$ Numerous tests are currently used for monitoring platelet functions in vitro. Many of them have been criticized because they do not reproduce the physiological conditions. ${ }^{(4)}$ None of the methods used for monitoring platelet functions is specific and sensitive enough. A standardized laboratory method for monitoring platelet functions is still lacking. Light transmission aggregometry (LTA), the current gold standard, evaluates luminosity as aggregation occurs in platelet-rich plasma following stimulation with a platelet agonist. ${ }^{\left({ }^{()}\right.}$Arachidonic acid, collagen, ADP (adenosine diphosphate), ristocetin, epinephrine or cationic propyl gallate (cPG) are the most commonly used inducers of platelet aggregation. Given the inter-individual and intra-individual variability of platelet aggregation, the results are reported as a percentage of baseline value. A significant correlation between aspirin resistance measured by LTA and the occurrence of primary endpoints (death, myocardial infarction or cerebrovascular events) in patients with stable cardiovascular disease has been reported. ${ }^{(9)}$ PFA-100 (Platelet Function Analyser-100) assesses platelet aggregation under high shear stress in whole blood. ASA-treated patients have been shown to have a relatively higher prevalence of short PFA-100 closure time because of higher normal levels of plasma von Willebrandt factor. ${ }^{(22)}$ PFA-100 is not able to detect the difference between a low and high ASA dose. ${ }^{(9,11)}$ One of the limitations of PFA-100 is an incorrect citrate concentration (which may shorten closure time). ${ }^{(12)}$ Whole blood aggregometry, VerifyNow Aspirin system, urinary 11-dehydro-thromboxane B2 measurement are also used to assess aspirin efficacy. Clopidogrel efficacy can be evaluated using turbidimetric (RPFA) or impedance methods, flow cytometry or LTA with ADP. ${ }^{(13)}$ The antiplatelet effect of clopidogrel is less expressed in citrate blood. ${ }^{(3)}$ No correlation has been found between different laboratory methods. ${ }^{(4)}$ Platelet function assays show great variability in differentiating between aspirinresistant and aspirin-sensitive patients. Neither of these assays correlates strongly with the current gold standard (LTA), or displays relevant agreement in determining aspirin resistance status. All assays should be tested to determine cut-off values, which can best predict clinical outcomes. ${ }^{(8)}$ It is not established as yet how to manage patients with ASA resistance. Dose enhancement may overcome ASA and clopidogrel resistance in individual patients, ${ }^{(2)}$ particularly in those who are partial responders. In vitro tests suggest clopidogrel may be effective in patients with aspirin resistance, but it was reported that $47 \%$ of aspirin-resistant individuals demonstrated also clopidogrel resistance. ${ }^{(14)}$ An increased loading or maintenance dose can be used in clopidogrel nonresponders. The ARMYDA- 2 trial showed the benefit of a higher clopidogrel loading dose. ${ }^{(2)}$ New P2Y12 receptor antagonists are currently undergoing investigation. ${ }^{(7)}$ New antiplatelet drugs (prasugrel, cangrelol, AZD6140) may have a potential benefit in clopidogrelresistant patients. These agents (AZD6140, cangrelol) exhibit more consistent and greater platelet inhibition, and short onset and offset of action compared to clopidogrel. ${ }^{(7,10)}$ The pharmacodynamic profile of prasugrel is superior to that of clopidogrel and is associated with a lower incidence of nonresponsiveness. ${ }^{(7)}$ Optimal management has not been determined yet. No consensus exists as to whether aspirinor clopidogrel-resistant patients should discontinue their therapy or whether additional therapy should be added. ${ }^{(3)}$ The existence of resistance to antiplatelet therapy has been reported in many studies, the major drawback of these studies is the lack of objective analysis of compliance. ${ }^{(15)}$ The limitations of prospective studies include a small sample size and the laboratory methods used. Until a reliable laboratory test allowing adequate analysis of aspirin resistance is identified, aspirin resistance should not be considered a novel clinical entity. ${ }^{(15)}$ It seems premature to categorize patients as resistant or responsive to antiplatelet therapy in a way that would reliably predict their clinical outcome and guide therapeutic decision-making. ${ }^{(15,22)}$ In conclusion, although clinical guidelines still do not support routine screening for antiplatelet drug resistance (because a standardized laboratory assay is still lacking), there is mounting evidence for the need to correlate the laboratory and clinical parameters of platelet activity assessment in different clinical scenarios.

\section{References}

1. Mckee SA, Sane DC, Deliargyris EN. Aspirin resistance in cardiovascular disease: a review of prevalence, mechanism, and clinical significance. Thromb Haemost 2002;8:711-5.

2. Wang TH, Bhatt DL, Topol EJ. Aspirin and clopidogrel resistance: an emerging clinical entity. Eur Heart J 2006;27:647-54.

3. Michos ED, Ardehali R, Blumenthal RS, Lange RA, Ardehali H. Aspirin and clopidogrel resistance. Mayo Clin Proc 2006;81:518-26.

4. Cattaneo M. Laboratory detection of "aspirin resistance" what test should we use (if any)? Eur Heart J 2007;28:1673-5.

5. Karetová D, Bultas J. Rezistence na aspirin - laboratorní odchylka nebo klinický problém? Interní medicína pro praxi 2005;1:10-3. 
6. Hankey GJ, Eikelboom JW. Aspirin resistance. Br Med J 2004;328:477-9.

7. Gurbel PA, Tantry US. Clopidogrel resistance? Throm Res 2007;120:311-21.

8. Lordkipanidze M, Pharand CH, Schampaert E, Turgeon J, Palisaitis DA, Diodati JG. A comparison of six major platelet function tests to determine the prevalence of aspirin resistance in patients with stable coronary artery disease. Eur Heart J 2007;702-8.

9. Altman R, Luciardi HL, Muntaner J, Herrera R. The antithrombotic profile of aspirin. Aspirin resistance, or simply failure? Thromb J 2004;2:1-8.

10. Angiolillo DJ, Ortiz AF, Bernardo E, et al. Variability in individual responsiveness to clopidogrel. J Am Coll Cardiol 2007;49:1505-16.

11. Malý J. Rezistence na kyselinu acetylsalicylovou. Interv Akut Kardiol 2005; 4:192-3.

12. Peterson P. Aspirin resistance: Fact and fiction. http://japan.medscape. com /viewarticle/518858.

13. Myers RI. The variability of platelet response to aspirin and clopidogrel revisiting the Caprie, Cure, Credo and Match trials. Proc Bayl Univ Med Cent 2005; 18:331-6.

14. Gupta S, Casterella PJ. Oral antiplatelet therapy resistance: Definition, diagnosis, and clinical implications. In: SIS 2007 Yearbook. Tremmel J, Christofferson RD (eds.) Seattle 2007;1-7, sponsored by Swedish Medical Center Foundation.
15. Violi F, Pignatelli P. The need for a consistent definition of "aspirin resistance". J Tromb Haemost 2006;4:1618-9.

16. Hulot JS, Bura A, Villard E, et al. Cytochrome P450 2C19 loss-of-function polymorphism is major determinant of clopidogrel responsiveness in healthy subjects. Blood 2006;108:2244-7.

17. Berrouschot J, Schwetlick B, Twickel G, et al. Aspirin resistance in secondary stroke prevention. Acta Neurol Scand 2006;113:31-5.

18. Deliargyris EN, Boudoulas H. Aspirin resistance. Hellenic J Cardiol 2004: 45:1-5.

19. Rocca $B$, Patrono $C$. Determinants of the interindividual variability in response to antiplatelet drugs. J Thromb Haemost 2005;3:1597-602.

20. Storey RF. Variability of response to antiplatelet therapy. Eur Heart J 2008;Suppl 10:A21-A27.

21. Storey RF. New developments in antiplatelet therapy, Emerging issues and new pharmacological options for P2Y12 inhibition in acute coronary syndromes (Abstracts ESC Congress 2007).

22. Szczeklik A, Musial J, Undas A, et al. Aspirin resistance. J Thromb Haemost 2005;3:1655-62.

Received 23 June 2008

Revision accepted 8 September 2008 